\title{
Short Communication Breast, ovarian, and endometrial malignancies in systemic lupus erythematosus: a meta-analysis
}

\author{
S Bernatsky*, I,2 R Ramsey-Goldman ${ }^{3}$, WD Foulkes ${ }^{4}$, C Gordon $^{5}$ and AE Clarke ${ }^{2,6}$ \\ 'Division of Rheumatology, McGill University Health Centre, Montreal, QC, Canada; ${ }^{2}$ Division of Clinical Epidemiology, Research Institute of the McGill \\ University Health Centre, 687 Pine Avenue West, V-Building, V2.09, Montreal, QC H3A IA I, Canada; ${ }^{3}$ Division of Rheumatology, Northwestern \\ University, Chicago, IL, USA; ${ }^{4}$ Program in Cancer Genetics, Departments of Oncology and Human Genetics, McGill University, Montreal, QC, Canada; \\ ${ }^{5}$ Department of Rheumatology, Sandwell and West Birmingham Hospitals NHS Trust, City Hospital, Birmingham, UK; ${ }^{6}$ Division of Clinical Immunology/ \\ Allergy, McGill University Health Centre, Montreal, QC, Canada
}

BACKGROUND: An increased lymphoma risk is well documented in systemic lupus (SLE). Less attention has been focused on women's cancers, even though SLE affects mostly females. Our objective was to estimate the risk of breast, ovarian, and endometrial cancers in SLE, relative to the general population.

METHODS: Data were included from five recent studies of large SLE cohorts. The number of cancers observed was determined for each cancer type. The expected number of malignancies was ascertained from general population data. The parameter of interest was the standardised incidence ratio (SIR), the ratio of observed to expected malignancies.

RESULTS: The five studies included 47325 SLE patients (42 I 7 I females) observed for 282553 patient years. There were 376 breast cancers, 66 endometrial cancers, and 44 ovarian cancers. The total number of cancers observed was less than that expected, with SIRs of $0.76(95 \% \mathrm{Cl}: 0.69,0.85)$ for breast cancer, $0.7 \mathrm{l}(95 \% \mathrm{Cl}: 0.55,0.9 \mathrm{I})$ for endometrial cancer, and 0.66 (95\% Cl: $0.49,0.90)$ for ovarian cancer.

CONCLUSIONS: Data strongly support a decreased risk of breast, ovarian, and endometrial cancers in SLE. This may be due to inherent differences in women in SLE (vs the general population) regarding endogenous oestrogen, other medications, and/or genetic make-up.

British Journal of Cancer (20II) I 04, 1478-148I. doi:I0.1038/bjc.201 I.II 5 www.bjcancer.com

Published online 12 April 20 I I

(c) 201 I Cancer Research UK

Keywords: systemic lupus; SLE; malignancy

An increased risk of lymphoma in systemic lupus erythematosus (SLE) has been the focus of much attention, particularly in the last decade (Gayed et al, 2009). However, as SLE is a disease predominantly of women, some of the most prevalent types of malignancies in SLE are actually those that commonly occur in women in the general population - breast, ovarian, and endometrial cancers. Despite this, much less attention has been focussed on these malignancies. Our objective was to estimate the risk of breast, ovarian, and endometrial cancers in women with SLE, relative to an age, calendar year, and geographically matched general population.

\section{METHODS}

A literature review was conducted to identify published peerreviewed articles documenting cancer occurrence in SLE, with a focus on observational cohort designs. It has been established (Furlan et al, 2006) that standard systematic literature searches do not effectively identify key manuscripts when observational

*Correspondence: Dr S Bernatsky; E-mail: sasha.bernatsky@mail.mcgill.ca Received 2 November 2010; revised 17 February 2011; accepted II March 20I I; published online 12 April 20I I designs are of primary interest. Thus, as per Furlan et al (2006), we completed a progressive literature search. This methodology involves identifying key articles from existing reviews of the literature, and then using search terms (in Medline, MeSH terms) from these citations to locate additional articles. Progressive search strategies locate essentially $100 \%$ of articles as compared with traditional systematic literature searches (Furlan et al, 2006).

For our analyses, we reviewed all cohort studies published since 1995, which provided basic descriptive information (regarding cohort assembly, demographics, person-time of observation, etc.), and cancer outcomes. The date of 1995 was chosen because the vast majority of the literature regarding cancer risk in SLE (including those with most rigorous methods) has been published in the last 10-15 years. However, several studies of cancer in SLE published since 1995 have come from centres that later contributed data to the international multi-centre cohort study of cancer in SLE, published in 2005 (Bernatsky et al, 2005b). Such studies were themselves excluded from our current analyses, as they were essential subset analyses of the larger multi-centre sample. To ensure the quality of the data included, we additionally required that outcome ascertainment was made through cancer registry linkage. The criteria for inclusion in our current analyses were thus as follows: studies of cancer occurrence in SLE cohorts published since 1995, where cancer registry linkage had been conducted to 
Table I Characteristics of the five recent large cohort studies of cancer in systemic lupus erythematosus

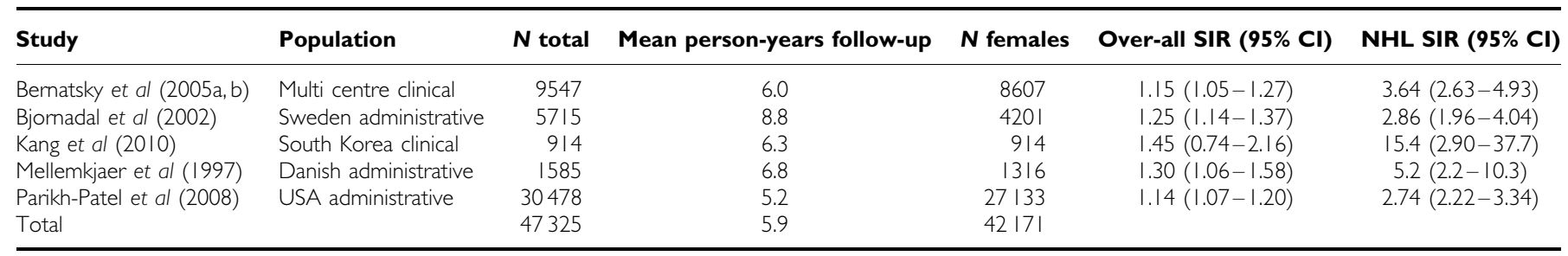

Abbreviations: SIR = standardised incidence ratio; $\mathrm{Cl}=$ confidence interval.

ascertain cancer occurrence, provided they were not replicated in other larger published data sets.

In our primary analysis, we did not consider random effects; the total number of cancers observed across all studies was summed for each of the three different cancer types (breast, endometrial, and ovarian). The total expected number of malignancies for each cancer type, derived in each study from applying general population cancer incidence data to the observed number of patient years of follow-up for each study, was similarly determined. Patients who contributed a cancer of one type could still contribute person-time and events for other cancer types. Our parameter of interest was the standardised incidence ratio (SIR), the ratio of observed to expected malignancies. The $95 \%$ confidence interval (CI) for each SIR was estimated by considering the observed number of cancers as a Poisson-distributed variable and finding its related interval from published tables (Breslow and Day, 1987).

The studies examined all patients in the cohort and did not exclude patients with a previous history of cancer. Of course cancer events that had occurred before SLE diagnosis (and cohort entry) were not included, but the patients with a history of previous cancer were still followed and contributed patient-time just like the others, and if they developed a cancer during the follow-up that event was included.

As SIRs for cancer may differ across centres, we also fit a random-effects hierarchical model allowing differences among studies, rather than assuming a single fixed rate across all. Standardised incidence ratio estimation using this hierarchical modelling represents a compromise between the summing of data across sites (our primary analysis, which assumes no variation in cancer experience from one centre to the next) $v s$ independent estimates for each centre (the other extreme, which would preclude estimation of a single SIR). We used the Gibbs sampler as implemented with WinBUGS 1.4 software to estimate the model parameters, with 95\% credible intervals (CrI) (Gelman et al, 1995).

\section{RESULTS}

Of the cohort studies of cancer occurrence in SLE that have been published since 1995, six provided data for the international cohort study published in 2005 (Bernatsky et al, 2005b). These smaller subset analyses (Sweeney et al, 1995; Abu-Shakra et al, 1996; Ramsey-Goldman et al, 1998; Sultan et al, 2000; Cibere et al, 2001; Nived et al, 2001) were excluded, whereas the larger international cohort study was included, along with four other large cohort studies from Sweden (Bjornadal et al, 2002), Denmark (Mellemkjaer et al, 1997), the United States (Parikh-Patel et al, 2008), and South Korea (Kang et al, 2010).

The five studies identified (Table 1) together included 47325 SLE patients (42171 of these female) observed for a total of 282553 patient years (mean 5.9 years). The overall cancer SIR for each study was in keeping with a slight increase in total cancer risk (which in each study had been demonstrated to be largely driven by an increased risk of haematological malignancy). In total, there were 376 breast cancers, 66 endometrial cancers, and 44 ovarian cancers. In each case, the total number of cancers expected far exceeded that observed, with SIRs of 0.76 (95\% CI: $0.69,0.85)$ for breast cancer, 0.71 (95\% CI: $0.55,0.91)$ for endometrial cancer, and 0.66 (95\% CI: $0.49,0.90)$ for ovarian cancer. Our random-effects model produced very similar findings, with an SIR of 0.76 (95\% CrI: $0.68,0.84)$ for breast cancer, 0.72 (95\% CrI: $0.56,0.91)$ for endometrial cancer, and 0.69 (95\% CrI: $0.50,0.90)$ for ovarian cancer.

\section{DISCUSSION}

In western countries, breast cancer has the highest incidence rate of all non-skin cancers (Curado et al, 2007). Endometrial cancer is the most common cancer of the female reproductive system and is one of the top five highest-incident cancers among women in the developed world (Curado et al, 2007). Like breast cancer, the risk of endometrial cancer increases with oestrogen exposure, both endogenously and via hormone replacement therapy (Pike et al, 1997). In addition, ovarian cancers may be precipitated by oestrogen exposure (Xu et al, 2004; Beral et al, 2007). In the general population, late menopause can increase both breast and endometrial cancer risk (La Vecchia et al, 1984; Peeters et al, 1994). Women with SLE have been shown to have earlier menopause (even when not exposed to cytotoxic medications), as compared with women without SLE (Cooper et al, 2002). This reproductive factor could be one of the driving forces behind the observed decreased risk of breast, endometrial, and possibly ovarian cancers in SLE. We are currently exploring this in a very large multicentre study of cancer incidence in SLE (Bernatsky et al, 2010). However, because our preliminary data suggest that breast cancer in SLE is decreased in both pre-menopausal and post-menopausal women, we suspect that there are additional factors contributing to a protective effect for certain cancers in SLE.

Other medication exposures are of interest. Hydroxychloroquine is an anti-malarial drug often used in SLE, and this has theoretically some potential to inhibit the growth of breast cancer cells (Rahim and Strobl, 2009). However, one earlier report of a potential beneficial effect of antimalarial agents against malignancy in rheumatic diseases like SLE (Ruiz-Irastorza et al, 2007) has not necessarily been supported by other studies (King and Costenbader, 2007; Bernatsky et al, 2008a). Intriguingly, although concerns have long existed regarding the carcinogenic potential of immunosuppressive drugs, results from a recent case-cohort study did not establish these agents as independently associated with cancer risk for non-haematological malignancies in SLE (Bernatsky et al, 2008b). In fact, there was a trend, although non-significant, towards fewer non-haematological malignancies treated with immunosuppressive agents (the adjusted hazard ratio for overall cancer risk after any immunosuppressive drug was 0.82 , 95\% CI $0.50-1.36$ ). Again, we are completing additional case-cohort analyses in the context of our expanded multi-centre international cohort study (Ruiz-Irastorza et al, 2007), which may be able to identify more precisely the role of these agents (relative to the risk related to the disease itself) in cancer risk for women with SLE. 
Table 2 Breast, ovarian, and endometrial cancers in systemic lupus erythematosus

\begin{tabular}{|c|c|c|c|c|c|}
\hline & 0 & $\mathbf{E}$ & SIR & \multicolumn{2}{|c|}{$95 \% \mathrm{Cl}$} \\
\hline \multicolumn{6}{|l|}{ Breast } \\
\hline Bernatsky & 73 & 96.1 & 0.76 & 0.60 & 0.96 \\
\hline Bjornadal & 52 & 72.2 & 0.72 & 0.54 & 0.94 \\
\hline Kang & 0 & 1.2 & 0 & 0.00 & 3.06 \\
\hline Mellemkjer & 14 & 14 & 1.00 & 0.55 & 1.68 \\
\hline Patel & 237 & 311.9 & 0.76 & 0.67 & 0.86 \\
\hline Total & 376 & 496.9 & 0.76 & 0.69 & 0.85 \\
\hline \multicolumn{6}{|l|}{ Endometrial } \\
\hline Bernatsky & 6 & 16.9 & 0.36 & 0.13 & 0.77 \\
\hline Bjornadal $^{a}$ & 26 & 24.4 & 1.07 & 0.70 & 1.56 \\
\hline Kang & । & 0.25 & 3.94 & 0.00 & 15.44 \\
\hline Mellemkjer & 4 & 3.1 & 1.29 & 0.35 & 3.30 \\
\hline Patel & 29 & 48.1 & 0.60 & 0.40 & 0.87 \\
\hline Total & 66 & 92.8 & 0.71 & 0.55 & 0.91 \\
\hline \multicolumn{6}{|l|}{ Ovarian } \\
\hline Bernatsky & 9 & 14.5 & 0.62 & 0.28 & 1.18 \\
\hline Bjornadal & 7 & 14.6 & 0.48 & 0.19 & 0.99 \\
\hline Kang & । & 0.38 & 2.62 & 0.04 & 14.65 \\
\hline Mellemkjer & 0 & 3.0 & 0.00 & 0.00 & 1.22 \\
\hline Patel & 27 & 32.8 & 0.82 & 0.54 & 1.20 \\
\hline Total & 44 & 65.3 & 0.66 & 0.49 & 0.90 \\
\hline
\end{tabular}

Abbreviations: $\mathrm{SIR}=$ standardized incidence ratio; $\mathrm{O}=$ observed cancers; $\mathrm{E}=$ expected cancers: $\mathrm{Cl}=$ confidence interval. In most cohorts the patients were primarily Caucasian, whereas the study of Kang et al featured Asian patients. anternational Classification of Diseases-9 code $171+174$.

Genetic factors might also underpin this association breast and ovarian cancers are components of several autosomal dominant cancer syndromes. The syndromes most strongly associated with both cancers are the $B R C A 1$ or $B R C A 2$ mutation syndromes (Narod et al, 1995), but these do not account for most breast cancers that arise in the general population. Genome-wide association studies have identified common variants (single nucleotide polymorphisms, (SNPs)) at various loci that are associated with an increased risk of breast cancer (Easton et al, 2007). Various genetic variants within $8 \mathrm{q} 24$ have been linked to breast, prostate, and other cancers (Ghoussaini et al, 2008). We are pursuing studies of data from genome-wide association studies in unselected SLE patients, to help to determine whether some of these specific cancer-related SNPs have a lower frequency than expected in persons with SLE.

\section{REFERENCES}

Abu-Shakra M, Gladman DD, Urowitz MB (1996) Malignancy in systemic lupus erythematosus. Arthritis Rheum 39: 1050-1054

Beral V, Bull D, Green J, Reeves G, Million Women Study Collaborators (2007) Ovarian cancer and hormone replacement therapy in the Million Women Study. Lancet 369: 1703-1710

Bernatsky S, Boivin JF, Joseph L, Manzi S, Ginzler E, Urowitz M, Gladman D, Fortin P, Gordon C, Barr S, Edworthy S, Bae SC, Petri M, Sibley J, Isenberg D, Rahman A, Steinsson K, Aranow C, Dooley MA, Alarcon GS, Hanly J, Sturfelt G, Nived O, Pope J, Ensworth S, Rajan R, El-Gabalawy H, McCarthy T, St Pierre Y, Clarke A, Ramsey-Goldman R (2005a) Race/ethnicity and cancer occurrence in systemic lupus erythematosus. Arthritis Rheum 53: $781-784$

Bernatsky S, Boivin JF, Joseph L, Rajan R, Zoma A, Manzi S, Ginzler E, Urowitz M, Gladman D, Fortin PR, Petri M, Edworthy S, Barr S, Gordon C, Bae SC, Sibley J, Isenberg D, Rahman A, Aranow C, Dooley MA, Steinsson K, Nived O, Sturfelt G, Alarcón G, Senécal JL, Zummer M, Hanly J, Ensworth S, Pope J, El-Gabalawy H, McCarthy T, St Pierre Y,
Regarding overall cancer risk, the data present do not include wash-out periods, but in our large multi-centre cohort we did in sensitivity analyses exclude the first year of SLE diagnosis to account for the potential of paraneoplastic syndromes. This did not change the results. We note that the study cohorts of Mellemkjer, Bjornadal, and Patel et al represented SLE patients drawn from hospitalisation records (where the SLE diagnosis was not necessarily clinically confirmed), whereas the study cohorts of Bernatsky and by Kang were drawn from clinical registries (and all subjects had clinically confirmed SLE. However, the follow-up time was not systematically different, and the SIR results were remarkably similar. One discernable difference in terms of demographics between the hospital-based cohorts and the clinical cohorts was that there was a tendency for a slightly greater proportion of males with the hospital-based cohort, but again this did not seem to influence the results.

Considering Table 2, the results are relatively homogeneous, but in some cases the data from Kang et al are a bit discrepant. In most cohorts the patients were primarily Caucasian, whereas the study of Kang et al featured Asian patients. This suggests that perhaps the cancer profile of SLE patients may be influenced by race. A potential limitation is that we did not have information about cancer risk stratified by race. However, race-specific SIRs for cancers overall have been published using data from the international multi-centre SLE cohort (Bernatsky et al, 2005a). Those analyses demonstrated similar SIRs for cancer risk overall in black and white patients with SLE, although precise estimates for Asians could not be demonstrated. As the multi-centre study is being updated, with twice as many patient years as previously, future data may help to resolve the issue (Bernatsky et al, 2010).

In summary, the published data to date strongly support a decreased risk of breast, ovarian, and endometrial malignancies in women with SLE. This may be due to inherent differences in women in SLE ( $v s$ the general population) with respect to endogenous oestrogen or other medications, and/or genetic make-up. Further studies may elucidate this.

\section{ACKNOWLEDGEMENTS}

Dr Sasha Bernatsky is a Canadian Arthritis Network Scholar and is supported by the Fonds de la Recherche en Santé du Québec (FRSQ) and the McGill University Health Centre Research Institute and Department of Medicine. Dr Clarke is a senior research fellow of the FRSQ.
Ramsey-Goldman R, Clarke A (2005b) An international cohort study of cancer in systemic lupus erythematosus. Arthritis Rheum 52: 1481-1490 Bernatsky S, Boivin JF, Gordon C, Joseph L, Urowitz M, Gladman D, Fortin PR, Ginzler E, Bae SC, Barr S, Edworthy S, Isenberg D, Rahman A, Petri M, Alarcón GS, Aranow C, Dooley MA, Rajan R, Sénécal JL, Zummer M, Manzi S, Ramsey-Goldman R, Clarke AE (2008a) The relationship between cancer and medication exposure in SLE. Ann Rheum Dis 67: 74-79

Bernatsky S, Clarke AE, Suissa S (2008b) Antimalarial drugs and malignancy: no evidence of a protective effect in risk in rheumatoid arthritis. Ann Rheum Dis 67: 277-278

Bernatsky S, Clarke A, Petri MA, Urowitz M, Fortin P, Gladman DD, Jacobsen S, Manzi S, Alarcon GS, Ginzler EM, Peschken CA, Dooley MA, Hanly JG, Nived O, Sturfelt GK, Senecal J-L, Labrecque J, Turnbull ET, Lee JLF (2010) Further defining cancer risk in systemic lupus: updated results in an expanded international multi-centre cohort [abstract]. Arthritis Rheum 62 (Suppl): S731 
Bjornadal L, Lofstrom B, Yin L, Lundberg I, Ekbom A (2002) Increased cancer incidence in a Swedish cohort of patients with systemic lupus erythematosus. Scand J Rheum 31: 66-71

Breslow NE, Day NE (1987) Statistical methods in cancer research: the design and analysis of cohort studies. WHO International Agency for Research on Cancer: Lyon, pp 302-304

Cibere J, Sibley J, Haga M (2001) Systemic lupus erythematosus and the risk of malignancy. Lupus 10: 394-400

Cooper GS, Dooley MA, Treadwell EL, St Clair EW, Gilkeson GS (2002) Hormonal and reproductive risk factors for development of systemic lupus erythematosus: results of a population-based, case-control study. Arthritis Rheum 46: 1830 - 1839

Curado MP, Edwards B, Shin HR, Storm H, Ferlay J, Heanue M, Boyle P (eds). (2007) Cancer Incidence in 5 Continents, Vol. IX. IARC Scientific Publications No. 160: IARC: Lyon

Easton DF, Pooley KA, Dunning AM, Pharoah PD, Thompson D, Ballinger DG, Struewing JP, Morrison J, Field H, Luben R, Wareham N, Ahmed S, Healey CS, Bowman R, Meyer KB, Haiman CA, Kolonel LK, Henderson BE, Le Marchand L, Brennan P, Sangrajrang S, Gaborieau V, Odefrey F, Shen CY, Wu PE, Wang HC, Eccles D, Evans DG, Peto J, Fletcher O, Johnson N, Seal S, Stratton MR, Rahman N, Chenevix-Trench G, Bojesen SE, Nordestgaard BG, Axelsson CK, Garcia-Closas M, Brinton L, Chanock S, Lissowska J, Peplonska B, Nevanlinna H, Fagerholm R, Eerola H, Kang D, Yoo KY, Noh DY, Ahn SH, Hunter DJ, Hankinson SE, Cox DG, Hall $P$, Wedren S, Liu J, Low YL, Bogdanova $N$, Schürmann $P$, Dörk T, Tollenaar RA, Jacobi CE, Devilee P, Klijn JG, Sigurdson AJ, Doody MM, Alexander BH, Zhang J, Cox A, Brock IW, MacPherson G, Reed MW, Couch FJ, Goode EL, Olson JE, Meijers-Heijboer $\mathrm{H}$, van den Ouweland A, Uitterlinden A, Rivadeneira F, Milne RL, Ribas G, Gonzalez-Neira A, Benitez J, Hopper JL, McCredie M, Southey M, Giles GG, Schroen C, Justenhoven C, Brauch H, Hamann U, Ko YD, Spurdle AB, Beesley J, Chen X, Mannermaa A, Kosma VM, Kataja V, Hartikainen J, Day NE, Cox DR, Ponder BA, SEARCH collaborators; kConFab; AOCS Management Group (2007) Genome-wide association study identifies novel breast cancer susceptibility loci. Nature 447(7148): $1087-1093$

Furlan A, Irwin E, Bombardier C (2006) Limited search strategies were effective in finding relevant nonrandomized studies. J Clin Epidemiol 59(12): $1303-1311$

Gayed M, Bernatsky S, Ramsey-Goldman R, Clarke A, Gordon C (2009) Lupus and cancer. Lupus 18(6): 479-485

Gelman A, Carlin J, Stern H, Rubin H (1995) Bayesian data analysis. Chapman and Hall: New York

Ghoussaini M, Song H, Koessler T, Al Olama AA, Kote-Jarai Z, Driver KE, Pooley KA, Ramus SJ, Kjaer SK, Hogdall E, DiCioccio RA, Whittemore AS, Gayther SA, Giles GG, Guy M, Edwards SM, Morrison J, Donovan JL, Hamdy FC, Dearnaley DP, Ardern-Jones AT, Hall AL, O’Brien LT, GehrSwain BN, Wilkinson RA, Brown PM, Hopper JL, Neal DE, Pharoah PD, Ponder BA, Eeles RA, Easton DF, Dunning AM, UK Genetic Prostate Cancer Study Collaborators/British Association of Urological Surgeons' Section of Oncology; UK ProtecT Study Collaborators (2008) Multiple loci with different cancer specificities within the 8q24 gene desert. J Natl Cancer Inst 100: $962-966$

Kang KY, Kim HO, Yoon HS, Lee J, Lee WC, Ko HJ, Ju JH, Cho CS, Kim HY, Park SH (2010) Incidence of cancer among female patients with systemic lupus erythematosus in Korea. Clin Rheumatol 29: 381-388

King J, Costenbader K (2007 Sep) Characteristics of patients with systemic lupus erythematosus (SLE) and non-Hodgkins lymphoma (NHL). Clin Rheumatol 26(9): $1491-1494$

La Vecchia C, Franceschi S, Decarli A, Gallus G, Tognoni G (1984) Risk factors for endometrial cancer at different ages. J Natl Cancer Inst 73: 667-671

Mellemkjaer L, Andersen V, Linet MS, Gridley G, Hoover R, Olsen JH (1997) Non-Hodgkin's lymphoma and other cancers among a cohort of patients with systemic lupus erythematosus. Arthritis Rheum 40: 761-768

Narod SA, Ford D, Devilee P, Barkardottir RB, Lynch HT, Smith SA, Ponder BA, Weber BL, Garber JE, Birch JM, Cornelis RS, Kelsell DP, Spurr NK, Smyth E, Haites N, Sobol H, Bignon Y-J, Chang-Claude J, Hamann U, Lindblom A, Borg A, Piver MS, Gallion HH, Struewing JP, Whittemore A, Tonin P, Goldgar DE, Easton DF (1995) An evaluation of genetic heterogeneity in 145 breast-ovarian cancer families: Breast Cancer Linkage Consortium. Am J Hum Genet 56: 254-264

Nived O, Bengtsson A, Jonsen A, Sturfelt G, Olsson H (2001) Malignancies during follow-up in an epidemiologically defined SLE inception cohort in southern Sweden. Lupus 10: 500-504

Parikh-Patel A, White RH, Allen M, Cress R (2008 Oct) Cancer risk in a cohort of patients with systemic lupus erythematosus (SLE) in California Cancer Causes Control. 19(8): 887-894

Peeters PMH, Verbeek AML, Krol A, Matthyssen MMM, de Waard F (1994) Age at menarche and breast cancer risk in nulliparous women. Breast Cancer Res Treat 33: 55-61

Pike MC, Peters RK, Cozen W, Probst-Hensch NM, Felix JC, Wan PC, Mack TM (1997) Estrogen-progestin replacement therapy and endometrial cancer. J Natl Cancer Inst 89: 1110-1116

Rahim R, Strobl JS (2009) Hydroxychloroquine, chloroquine, and all-trans retinoic acid regulate growth, survival, and histone acetylation in breast cancer cells. Anticancer Drugs 20: 736-745

Ramsey-Goldman R, Mattai SA, Schilling E, Chiu YL, Alo CJ, Howe HL (1998) Increased risk of malignancy in patients with systemic lupus erythematosus. J Investig Med 46: 217-222

Ruiz-Irastorza G, Ugarte A, Egurbide MV, Garmendia M, Pijoan JI, MartinezBerriotxoa A, Aguirre C (2007) Antimalarials may influence the risk of malignancy in systemic lupuserythematosus. Ann Rheum Dis 66: 815-817

Sultan SM, Ioannou Y, Isenberg DA (2000) Is there an association of malignancy with systemic lupus erythematosus? An analysis of 276 patients under long-term review. Rheumatology: Oxford 39: 1147-1152

Sweeney DM, Manzi S, Janosky J, Selvaggi KJ, Ferri W, Medsger Jr TA, Ramsey-Goldman R (1995) Risk of malignancy in women with SLE. J Rheumatol 22: $1478-1482$

Xu W, Xiang Y, Ruan Z, Zheng W, Cheng J, Dai Q, Gao YT, Shu XO (2004) Menstrual and reproductive factors and endometrial cancer risk: results from a population-based case-control study in urban Shanghai. Int $J$ Cancer 108: 613-619 